\title{
Study of Common Quantification Methods of Amide Proton Transfer Magnetic Resonance Imaging for Ischemic Stroke Detection
}

Lee Sze Foo, B.S, a, James R Larkin, PhD, b, Brad A. Sutherland, PhD, c, d, Kevin J. Ray, DPhil, b, Wun-She Yap, PhD, e, Yan Chai Hum, PhD, a, Khin Wee Lai, PhD, , Hanani Abdul Manan,

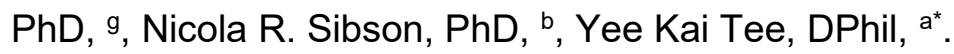

a Department of Mechatronics and Biomedical Engineering, Lee Kong Chian Faculty of Engineering and Science, Universiti Tunku Abdul Rahman, Malaysia.

b Department of Oncology, Cancer Research UK and Medical Research Council Oxford Institute for Radiation Oncology, University of Oxford, UK.

${ }^{c}$ Tasmanian School of Medicine, College of Health and Medicine, University of Tasmania, Australia.

d Acute Stroke Programme, Radcliffe Department of Medicine, University of Oxford, United Kingdom.

e Department of Electrical and Electronic Engineering, Lee Kong Chian Faculty of Engineering and Science, Universiti Tunku Abdul Rahman, Malaysia.

f University of Malaya, Faculty of Engineering, Department of Biomedical Engineering, Jalan Universiti, Kuala Lumpur, 50603, Malaysia

g Department of Radiology, Universiti Kebangsaan Malaysia Medical Centre, Malaysia.

*Corresponding Author

Yee Kai Tee

Email address: teeyeekai@gmail.com

This Supplementary Material file contains:

I. Summary of APT Quantification Methods for Ischemic Stroke Imaging

II. $\quad$ MR Images of Animals 5 and 6

III. Ischemic Areas of CBF, APT, and ADC images of Animals 5 and 6

IV. Differences between the Quantified APT effects (values) within the APT Ischemic Areas

$V$. Ischemic Areas of $T_{1}$ and $T_{2}$ of Animals $1-6$

VI. Averaged Ischemic and Contralateral Z-Spectra of Animals $1-6$

VII. K-means Clusters of Quantified Values of APT Quantification Methods of Animals 1 - 6

VIII. Changes in Quantified MTR asym $(\sim 3.5$ ppm) During Ischemic Stroke 


\section{Summary of APT Quantification Methods for Ischemic Stroke Imaging}

Various quantification methods have been proposed for amide proton transfer (APT) ischemic stroke imaging. Supporting Table S1 below summarizes the APT quantification methods used for ischemic stroke imaging and the respective advantages and limitations. In general, the quantification methods can be separated into two categories - model-free and model-based methods.

Supporting Table S1. Summary of APT quantification methods for ischemic stroke imaging. The most commonly used methods based on literature are shown in bold font; quantification methods used in the present study are underlined. The white shaded entries are model-free methods; gray shaded entries are model-based methods.

\begin{tabular}{|c|c|c|c|}
\hline Method & Advantages & Limitations & References \\
\hline $\begin{array}{l}\frac{\text { Magnetization }}{\text { transfer ratio }} \\
\frac{\text { asymmetry (MTR }}{\text { asym })}\end{array}$ & $\begin{array}{l}\text { - Computationally simplistic and fast. } \\
\text { - Able to generate } \mathrm{pH} \text {-weighted image } \\
\text { that correlates reasonably well with } \\
\text { pathology. }\end{array}$ & $\begin{array}{l}\text { Contaminated by RF spillover, MT } \\
\text { effects, nuclear Overhauser } \\
\text { enhancement (NOE) effects, as well as } \\
\text { CEST effects of other endogenous } \\
\text { exchangeable protons which causes a } \\
\text { reduction in sensitivity of APT signals. }\end{array}$ & $(1-37)$ \\
\hline $\begin{array}{l}\text { Complementary } \\
\text { MTR }{ }_{\text {asym }} \\
\left(\text { MTR }_{\text {asym_comp }}\right)\end{array}$ & $\begin{array}{l}\text { - } \quad \text { Computationally simplistic and fast. } \\
\text { - Improves contrast-to-noise ratio (CNR) } \\
\text { between non-ischemic and ischemic } \\
\text { tissue compared to MTR } \text { Rasym. }^{\text {. }}\end{array}$ & $\begin{array}{l}\text { Contaminated by RF spillover and MT } \\
\text { effects as well as CEST effects of other } \\
\text { endogenous exchangeable protons. }\end{array}$ & $(7,38)$ \\
\hline $\begin{array}{l}\text { Apparent APT (APT*) } \\
\text { / three-offset method }\end{array}$ & $\begin{array}{l}\text { - Computationally simplistic and fast. } \\
\text { - No NOE effects since negative offsets } \\
\text { are not used as the reference. } \\
\text { Improves on MTR } \text { Iasym, in that it }_{\text {increases the relative contrast between }} \\
\text { ischemic lesion and contralateral tissue, } \\
\text { compared to contrast within } \\
\text { contralateral normal-appearing tissue. }\end{array}$ & $\begin{array}{l}\text { Not very suitable for clinical use, as it is } \\
\text { only suitable for higher field strength } \\
\text { experiments since it assumes the z- } \\
\text { spectrum to be approximately linear } \\
\text { between the lower and upper } \\
\text { boundaries of the APT dip which may } \\
\text { only be true if the APT dip is narrow and } \\
\text { well defined. } \\
\text { Bandwidth of the saturation pulse } \\
\text { should be kept as narrow as possible. } \\
\text { However, in the clinical setting, short } \\
\text { saturation pulses are typically used. }\end{array}$ & $(5,21,27)$ \\
\hline
\end{tabular}




\begin{tabular}{|c|c|c|c|}
\hline & & $\begin{array}{l}\text { - Is highly dependent on the definition of } \\
\text { APT dip boundaries thus requires higher } \\
\text { sampling rate near APT resonance to } \\
\text { accurately identify these boundaries. }\end{array}$ & \\
\hline $\begin{array}{l}T_{1-\text { normalized }} \\
\text { MTR } \\
\text { asym }\end{array}$ & $\begin{array}{l}\text { - } \quad \text { Computationally simplistic and fast. } \\
\text { - Improves correlation of quantified APT } \\
\text { effect with intracellular pH compared to } \\
\text { MTR }_{\text {asym. }}\end{array}$ & $\begin{array}{l}\text { - } \text { Requires } \mathrm{T}_{1} \text { information. } \\
\text { - Does not correct for MT effect and other } \\
\text { contaminants. }\end{array}$ & $(17,19,37)$ \\
\hline $\begin{array}{l}\text { Apparent exchange- } \\
\text { dependent relaxation } \\
\text { (AREX) }\end{array}$ & $\begin{array}{l}\text { - Computationally simplistic and fast. } \\
\text { - Corrects for spillover effect and MT } \\
\text { effects. } \\
\text { - Increases CNR between ischemic lesion } \\
\text { and non-ischemic tissue, compared to } \\
\text { MTR Rasym. }\end{array}$ & $\begin{array}{l}\text { - } \text { Requires } T_{1} \text { information. } \\
\text { - Not suitable for low power RF saturation } \\
\text { as it assumes RF saturation power } B_{1} \text { to } \\
\text { be much larger than the amide } \\
\text { exchange rate. } \\
\text { - Not suitable for low field strength or in } \\
\text { the presence of large spillover effects } \\
\text { and MT effects as it is prone to break } \\
\text { down near } 0 \text { ppm due to the use of } \\
\text { inverse analysis. }\end{array}$ & $(27,39,40)$ \\
\hline $\begin{array}{l}\text { Enhancing } \mathrm{pH}- \\
\text { sensitivity via } \\
\text { combination of amide } \\
\text { and guanidyl - } \mathrm{pH}_{\mathrm{enh}}\end{array}$ & $\begin{array}{l}\text { - Computationally simplistic and fast. } \\
\text { - Corrects for spillover effects. } \\
\text { - Higher homogeneity in non-ischemic } \\
\text { tissue, and increases CNR between } \\
\text { contralateral and ischemic tissue, when } \\
\text { compared to MTR } \text { asym. }^{\text {as }}\end{array}$ & $\begin{array}{l}\text { Not suitable for low field strength } \\
\text { experiments since CEST effect of } \\
\text { guanidyl at } 2.0 \text { ppm is not very visible. }\end{array}$ & (14) \\
\hline $\begin{array}{l}\text { Magnetization } \\
\text { transfer and } \\
\text { relaxation- } \\
\text { normalized APT } \\
\text { (MRAPT) analysis }\end{array}$ & $\begin{array}{l}\text { Better homogeneity in contralateral } \\
\text { normal-appearing tissue. } \\
\text { - Enhanced pH specificity compared to } \\
\text { MTR Rasym. }^{\text {- }}\end{array}$ & $\begin{array}{l}\text { May not be suitable for later stage } \\
\text { stroke imaging as it assumes that } \mathrm{T}_{1} \text {, } \\
\text { MTR, and amide proton concentration } \\
\text { have little change; may be valid during } \\
\text { the acute phase but more studies are } \\
\text { required for beyond acute stage. }\end{array}$ & $\begin{array}{l}(12,25,28,3 \\
1)\end{array}$ \\
\hline $\begin{array}{l}\text { Lorentzian } \\
\text { difference analysis } \\
\text { (LDA) }\end{array}$ & $\begin{array}{l}\text { - More homogenous quantification in non- } \\
\text { ischemic tissue compared to model-free } \\
\text { methods. }\end{array}$ & $\begin{array}{l}\text { - May tend to overestimate APT effect. } \\
\text { - Not suitable for higher power pulsed RF } \\
\text { irradiations because the CEST dip is }\end{array}$ & $\begin{array}{l}6,21,27,41, \\
42)\end{array}$ \\
\hline
\end{tabular}




\begin{tabular}{|c|c|c|c|}
\hline & $\begin{array}{l}\text { - Not as time consuming compared to } \\
\text { multi-pool Bloch-McConnell model } \\
\text { fitting. }\end{array}$ & $\begin{array}{l}\text { broader due to shorter pulses being } \\
\text { used (higher bandwidth, broader } \\
\text { saturation) and spillover. }\end{array}$ & \\
\hline $\begin{array}{l}\text { Multi-Lorentzian } \\
\text { fitting }\end{array}$ & $\begin{array}{l}\text { - More homogenous quantification of non- } \\
\text { ischemic tissue compared to MTR } \text { asym. }_{\text {- }} \text { Less susceptible to error due to noise } \\
\text { compared to model-free methods. } \\
\text { - Not as time consuming compared to } \\
\text { multi-pool Bloch-McConnell model } \\
\text { fitting. }\end{array}$ & $\begin{array}{l}\text { - Requires some prior knowledge of the } \\
\text { model, e.g. the number of pools to fit. } \\
\text { - Improper boundary and initial values } \\
\text { may cause biased fitting. } \\
\text { - Not suitable for high power pulsed RF } \\
\text { irradiations because the CEST dip is } \\
\text { broader due to shorter pulses being } \\
\text { used (higher bandwidth, broader } \\
\text { saturation) and spillover. }\end{array}$ & $(17,41-43)$ \\
\hline $\begin{array}{l}\text { Image Downsampling } \\
\text { Expedited Adaptive } \\
\text { Least-Squares } \\
\text { (IDEAL) fitting }\end{array}$ & $\begin{array}{l}\text { - Less susceptible to small variations due } \\
\text { to noise compared to multi-Lorentzian } \\
\text { fitting. }\end{array}$ & $\begin{array}{l}\text { - Slightly more time constraining as } \\
\text { multiple rounds of multi-Lorentzian } \\
\text { fitting is needed. }\end{array}$ & $(44,45)$ \\
\hline $\begin{array}{l}\text { Quantitative APT } \\
\left(\mathrm{APT}^{\#}\right) \text { via } \\
\text { extrapolated semisolid } \\
\text { magnetization transfer } \\
\text { reference (EMR) data } \\
\text { analysis }\end{array}$ & $\begin{array}{l}\text { - } \quad \text { Corrects for MT effects. } \\
\text { Increases contrast between ischemic } \\
\text { lesion and non-ischemic tissue } \\
\text { compared to MTR Rasym. }\end{array}$ & $\begin{array}{l}\text { For more accurate EMR data fitting, } \\
\text { finer sampling around } 8-14 \text { ppm is } \\
\text { needed, which increases scan time. }\end{array}$ & $(15,46)$ \\
\hline $\begin{array}{l}\text { Multi-pool Bloch- } \\
\text { McConnell model } \\
\text { fitting }\left(\text { APTR* }^{*}\right)\end{array}$ & $\begin{array}{l}\text { - Higher homogeneity in non-ischemic } \\
\text { tissue. } \\
\text { - Higher CNR between ischemic lesion } \\
\text { and normal tissue compared to model- } \\
\text { free methods. } \\
\text { - Quantitative fitted parameters may be } \\
\text { useful for personalized healthcare. } \\
\text { - Less susceptible to error due to noise } \\
\text { compared to model-free methods. }\end{array}$ & $\begin{array}{l}\text { Very time consuming, especially with } \\
\text { pulsed RF irradiation schemes used in } \\
\text { clinical scanners. } \\
\text { Tends to overfit the data when the } \\
\text { number of pools modelled or the } \\
\text { parameters to fit is more than the } \\
\text { informative CEST data points collected. }\end{array}$ & $\begin{array}{l}(7,27,47- \\
49)\end{array}$ \\
\hline
\end{tabular}


In this present study, only some of the most commonly used APT quantification methods were used for analysis (underlined in Supporting Table S1). Other methods were excluded due to unsuitable experimental parameters as the study was a retrospective analysis. The quantification methods used in the main manuscript are defined as follows:

\section{Magnetization Transfer Ratio Asymmetry (MTR $\left.{ }_{\text {asym }}\right)$}

MTR $_{\text {asym }}$ is an asymmetry analysis method calculated as the difference between the saturated signal at opposite frequency offset of amide proton resonance, $S(-3.5 \mathrm{ppm})$ and at amide proton resonance, $S(+3.5 \mathrm{ppm})$, normalized by the unsaturated signal, $S_{0}(1)$ :

$$
\operatorname{MTR}_{\text {asym }}(3.5 \mathrm{ppm})=\frac{S(-3.5 \mathrm{ppm})-S(+3.5 \mathrm{ppm})}{S_{0}} .
$$

This method is contaminated by water spillover, MT effect, nuclear Overhauser enhancement (NOE) effects, as well as competing CEST effects of other endogenous exchangeable protons, causing a reduction in the sensitivity of APT signals. Nevertheless, due to its simplistic and fast computation, this method remains as the most commonly used quantification method for APT imaging in stroke (1-37).

In the effort to achieve a pure quantified APT effect, many studies have sought to improve on MTR $_{\text {asym }}$ and minimize the contaminant effects by modifying or correcting MTR asym.

\section{$\underline{1}_{1-\text {-normalized MTR }}$ asym}

$\mathrm{T}_{1}$-normalized MTR $\mathrm{R}_{\text {asym }}$ involves performing voxel-wise normalization of the quantified $\mathrm{MTR}_{\text {asym }}$ (3.5 ppm) with respect to $\mathrm{T}_{1}(17,19,37)$ :

$$
\mathrm{T}_{1} \text {-norm MTR } \mathrm{Masym}(+3.5 \mathrm{ppm})=\frac{\mathrm{MTR}_{\mathrm{asym}}(+3.5 \mathrm{ppm})}{\mathrm{T}_{1}} .
$$

This compensates for water relaxation and improves the correlation between $\mathrm{MTR}_{\text {asym }}(+3.5 \mathrm{ppm})$ with intracellular $\mathrm{pH}$, while still maintaining computational speed due to its simple calculation.

\section{Apparent Exchange-Dependent Relaxation (AREX)}

AREX is first calculated by taking the difference between the inverse of the saturated signal at $+3.5 \mathrm{ppm}$, and the inverse of the reference signal instead, both normalized by the unsaturated 
signal, $S_{0}$ :

$$
\operatorname{MTR}_{\text {Rex }}(+3.5 \mathrm{ppm})=\left(\frac{S(+3.5 \mathrm{ppm})}{S_{0}}\right)^{-1}-\left(\frac{S_{r e f}}{S_{0}}\right)^{-1}
$$

where $S_{r e f}$ is the reference signal.

This analytically removes the transverse relaxation term $\mathrm{T}_{2}$ of water saturation and symmetric MT contributions. Then, to compensate for water longitudinal relaxation $T_{1}, M T R_{R e x}$ is normalized by $\mathrm{T}_{1}$ to produce AREX $(27,39,40)$ :

$$
\operatorname{AREX}(+3.5 \mathrm{ppm})=\frac{\mathrm{MTR}_{\mathrm{Rex}}(+3.5 \mathrm{ppm})}{\mathrm{T}_{1}} .
$$

The reference signal in Eq. (3) may be the measured signal at the opposite frequency offset, $S(-3.5 \mathrm{ppm})$, the averaged signals of the lower $S_{l}$ and upper bounds $S_{u}$ of the APT dip, or fitted single-pool Lorentzian lineshape.

\section{Lorentzian Difference Analysis (LDA)}

LDA involves fitting the normalized z-spectrum to the Lorentzian lineshape model $(41,42)$ :

$$
L(\omega)=Z_{\mathrm{base}}-\sum_{i=1}^{N} A_{i} \frac{\Gamma_{i}^{2} / 4}{\Gamma_{i}^{2} / 4+\left(\omega-\delta_{i}\right)^{2}},
$$

where $A_{i}$ is the amplitude, $\Gamma_{i}$ is the full wave half maximum (FWHM), $\delta_{i}$ is the resonant frequency of the pool, $N$ is the total number of pools modelled, and $Z_{\text {base }}$ is a constant or baseline that accounts for the constant signal reduction. In LDA, a one-pool model of water is used to eliminate direct water saturation.

The APT effect is then quantified by taking the difference between the fitted Lorentzian lineshape and the normalized measured signal at $3.5 \mathrm{ppm}(6,21,27,41,42)$ :

$$
\mathrm{LDA}=L(+3.5 \mathrm{ppm})-\frac{S(+3.5 \mathrm{ppm})}{S_{0}} .
$$




\section{Multi-Lorentzian Fitting}

Similar to LDA, multi-Lorentzian fitting is also a Lorentzian model-based method. In this method, the normalized z-spectrum fitted to the Lorentzian lineshape model in Eq. (5), but instead, all of the visible CEST contributions in the z-spectrum are fitted, where $N$ is the total number of pools observable in the collected z-spectra. The fitting process effectively isolates each individual CEST effect in order to achieve a pure APT quantification.

The quantified APT effect is the fitted amplitude of the amide pool at $+3.5 \mathrm{ppm}, A_{\text {amide }}(17,41-43)$. Some also use the fitted linewidth, $\Gamma_{\text {amide}}$, but fitted amplitude is more common. 


\section{MR Images of Animals 5 and 6}

Supporting Figure $\mathrm{S} 1$ below shows the ADC, $\mathrm{T}_{1}, \mathrm{~T}_{2}$, and APT images of Animals 5 and 6 . Similar to Animals $1-4$ in the main manuscript, the ischemic areas in the APT images generated by the different quantification methods were hypointense compared to non-ischemic tissue. It could also be observed that the ischemic areas of each APT image were different from one another in terms signal variations and in the ischemic area sizes.

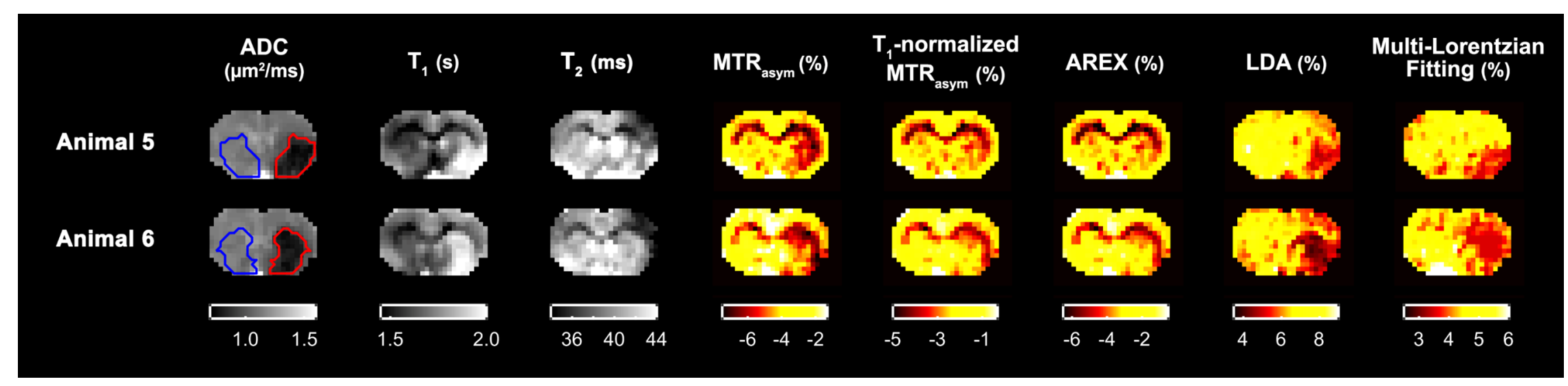

Supporting Figure S1. MR images of Animals 5 and 6 that were subject to MCAO. The first column shows the ADC images ( $\left.\mu m^{2} / \mathrm{ms}\right)$, overlaid with the ischemic (red) and contralateral (blue) regions of interest (ROI). The second and third column show the $\mathrm{T}_{1}(\mathrm{~s})$ and $\mathrm{T}_{2}$ maps (ms); subsequent columns correspond to APT images generated using different quantification methods: MTR $\mathrm{R}_{\text {asym, }} \mathrm{T}_{1}$-normalized MTR ${ }_{\text {asym, }}$ AREX, LDA, and multi-Lorentzian fitting (\%). The final row shows the relative quantified APT effects of all six animals $(n=6)$ within the contralateral and ischemic tissues of each quantification method; * indicates a significant difference between the two tissues at $5 \%$ significance level. 


\section{Ischemic Areas of CBF, APT, and ADC images of Animals 5 and 6}

Supporting Figure S2 shows the ADC, CBF, and APT images of Animals 5 and 6, with the respective ischemic areas: green - CBF, blue - APT, and white - ADC. For each animal, the ADC and APT images are shown in the top row with the ADC and APT ischemic areas outlined in white and blue respectively. The final column in the top row shows the overlapped APT ischemic binary masks of all five quantification methods, where higher intensity indicates a higher overlap. Similar to the findings for Animals $1-4$ in the main manuscript, although each APT predicted ischemic lesions of different quantification methods coincided well with the ADC lesion, but varied in sizes beyond the ADC deficit area, evident in the APT lesion overlapping map in the last column.

When comparing the CBF/APT/ADC ischemic area mismatches shown in the bottom row, the model-free methods - MTR asym, $_{1}$-normalized $M T R_{\text {asym, }}$ and AREX produced APT lesion predictions that were larger than the ADC deficits but smaller than CBF deficits. The Lorentzian model-based methods on the other hand, produced APT lesion areas that were comparable in size to the CBF deficits. However, it was not possible to further verify these findings with the pathophysiology of the animals in this retrospective study. 


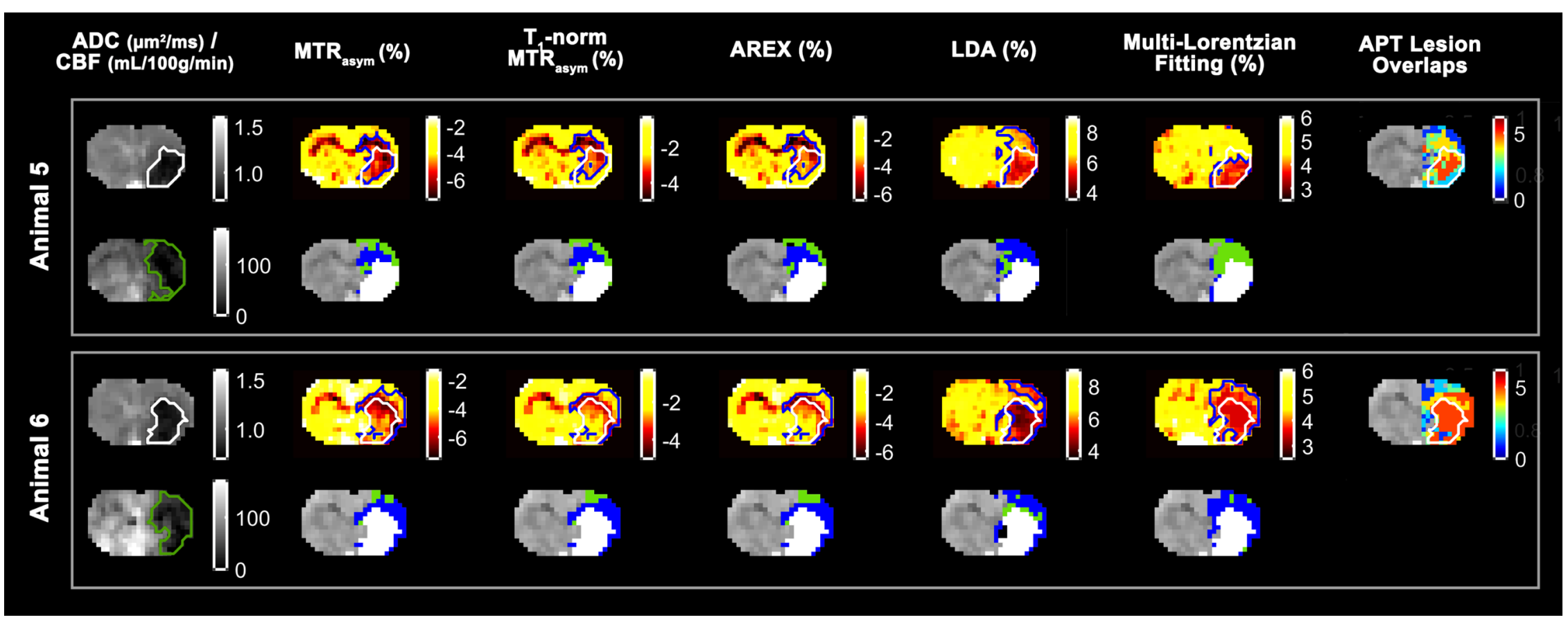

Supporting Figure S2. ADC $\left(\mu \mathrm{m}^{2} / \mathrm{ms}\right)$, CBF ( $\left.\mathrm{mL} / 100 \mathrm{~g} / \mathrm{min}\right)$, and APT (\%) images of Animals 5 and 6 , with the respective ischemic areas outlined: ADC - white, CBF - green, and APT - blue. For every animal, the ADC and APT images are shown in the top row along with the binary ischemic area overlaps of all five APT methods in the last column, where higher intensity indicates a higher overlap. The bottom row shows the CBF map as well as the CBF/APT/ADC lesion mismatches of every APT quantification method; the display priority in the mismatch plots is white $>$ blue $>$ green. 
IV. Differences between the Relative Quantified APT Effects (values) within the APT Ischemic Areas

Supporting Table S2(a) - (f) below shows the $P$-values of the Mann-Whitney $U$ test between the relative quantified APT effects (values) within the APT predicted ischemic areas, obtained using the different quantification methods, for each animal. Here, bold font indicates a significant difference $(P<0.05)$.

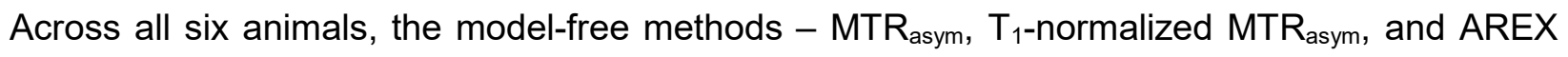
produced relative APT effects that were significantly different from those quantified using Lorentzian model-based methods - LDA and multi-Lorentzian fitting.

Among the model-free methods, the relative quantified APT effects using MTR asym and AREX were found to be significantly different from one another in all six animals. The relative quantified effects using MTR asym and $T_{1}$-normalized MTR $R_{\text {asym }}$, were also found to be significantly different in the animals, except in Animal 5. Conversely, AREX and $\mathrm{T}_{1}$-normalized MTR asym, were not found to produce significant differences in any of the animals.

As for the Lorentzian model-based methods, LDA and multi-Lorentzian fitting relative quantified effects were only found to be significantly different in Animal 2.

To summarize, generally, the relative quantified APT effects using the different quantification methods had large signal variations from one another, with the exception of the pairs: $\mathrm{T}_{1}$ normalized $M T R_{\text {asym }}-A R E X$, and LDA - multi-Lorentzian fitting.

Supporting Table S2(a). $P$-values of Mann-Whitney $U$ test between the relative quantified effects (values) in the APT ischemic lesions of Animal 1 using the different quantification methods. Bold font indicates a significant difference $(P<0.05)$.

\begin{tabular}{|c|c|c|c|c|}
\hline \multicolumn{5}{|c|}{ Animal 1} \\
\hline $\begin{array}{l}\text { Quantification } \\
\text { Method }\end{array}$ & $\begin{array}{l}\text { T1-normalized } \\
\text { MTRasym }\end{array}$ & AREX & LDA & $\begin{array}{c}\text { Multi-Lorentzian } \\
\text { Fitting }\end{array}$ \\
\hline MTRasym & $4.239 \times 10^{-4}$ & $1.742 \times 10^{-5}$ & $6.069 \times 10^{-35}$ & $1.270 \times 10^{-35}$ \\
\hline $\begin{array}{l}\text { T1-normalized } \\
\text { MTRasym }\end{array}$ & & $3.023 \times 10^{-1}$ & $2.230 \times 10^{-35}$ & $4.477 \times 10^{-36}$ \\
\hline AREX & & & $7.745 \times 10^{-37}$ & $1.35 \times 10^{-37}$ \\
\hline LDA & & & & $8.762 \times 10^{-1}$ \\
\hline
\end{tabular}


Supporting Table S2(b). $P$-values of Mann-Whitney $U$ test between the relative quantified effects (values) in the APT ischemic lesions of Animal 2 using the different quantification methods. Bold font indicates a significant difference $(P<0.05)$.

\begin{tabular}{|c|c|c|c|c|}
\hline \multicolumn{5}{|c|}{ Animal 2} \\
\hline $\begin{array}{l}\text { Quantification } \\
\text { Method }\end{array}$ & $\begin{array}{l}\text { T1-normalized } \\
\text { MTRasym }\end{array}$ & AREX & LDA & $\begin{array}{c}\text { Multi-Lorentzian } \\
\text { Fitting }\end{array}$ \\
\hline MTRasym & $6.310 \times 10^{-3}$ & $6.932 \times 10^{-4}$ & $1.082 \times 10^{-50}$ & $2.283 \times 10^{-51}$ \\
\hline $\begin{array}{l}\text { T1-normalized } \\
\text { MTRasym }\end{array}$ & & $4.024 \times 10^{-1}$ & $4.908 \times 10^{-49}$ & $1.324 \times 10^{-49}$ \\
\hline AREX & & & $7.436 \times 10^{-49}$ & $2.11 \times 10^{-49}$ \\
\hline LDA & & & & $8.400 \times 10^{-7}$ \\
\hline
\end{tabular}

Supporting Table S2(c). $P$-values of Mann-Whitney $U$ test between the relative quantified effects (values) in the APT ischemic lesions of Animal 3 using the different quantification methods. Bold font indicates a significant difference $(P<0.05)$.

\begin{tabular}{|l|c|c|c|c|}
\hline $\begin{array}{l}\text { Quantification } \\
\text { Method }\end{array}$ & $\begin{array}{c}\text { T1-normalized } \\
\text { MTRasym }\end{array}$ & AREX & LDA & $\begin{array}{c}\text { Multi-Lorentzian } \\
\text { Fitting }\end{array}$ \\
\hline MTRasym & $1.893 \times 10^{-2}$ & $\mathbf{6 . 4 5 2 \times 1 0 ^ { - 3 }}$ & $\mathbf{5 . 2 8 8 \times 1 0 ^ { - 3 5 }}$ & $\mathbf{3 . 8 0 3 \times 1 0 ^ { - 3 5 }}$ \\
\hline $\begin{array}{l}\text { T1-normalized } \\
\text { MTRasym }\end{array}$ & & $6.292 \times 10^{-1}$ & $\mathbf{8 . 1 1 9 \times 1 0 ^ { - 3 5 }}$ & $\mathbf{5 . 8 6 \times 1 0 ^ { - 3 5 }}$ \\
\hline AREX & & & $\mathbf{8 . 1 1 9 \times 1 0 ^ { - 3 5 }}$ & $\mathbf{5 . 8 6 \times 1 0 ^ { - 3 5 }}$ \\
\hline LDA & & & & $2.925 \times 10^{-1}$ \\
\hline
\end{tabular}

Supporting Table S2(d). $P$-values of Mann-Whitney $U$ test between the relative quantified effects (values) in the APT ischemic lesions of Animal 4 using the different quantification methods. Bold font indicates a significant difference $(P<0.05)$.

\begin{tabular}{|c|c|c|c|c|}
\hline \multicolumn{5}{|c|}{ Animal 4} \\
\hline $\begin{array}{l}\text { Quantification } \\
\text { Method }\end{array}$ & $\begin{array}{l}\text { T1-normalized } \\
\text { MTRasym }\end{array}$ & AREX & LDA & $\begin{array}{c}\text { Multi-Lorentzian } \\
\text { Fitting }\end{array}$ \\
\hline MTRasym & $1.990 \times 10^{-3}$ & $3.282 \times 10^{-3}$ & $6.269 \times 10^{-36}$ & $3.821 \times 10^{-28}$ \\
\hline $\begin{array}{l}\text { T1-normalized } \\
\text { MTRasym }\end{array}$ & & $9.840 \times 10^{-1}$ & $2.68 \times 10^{-35}$ & $9.192 \times 10^{-28}$ \\
\hline AREX & & & $8.271 \times 10^{-35}$ & $1.825 \times 10^{-27}$ \\
\hline
\end{tabular}




\section{LDA}

Supporting Table S2(e). $P$-values of Mann-Whitney $U$ test between the relative quantified effects (values) in the APT ischemic lesions of Animal 5 using the different quantification methods. Bold font indicates a significant difference $(P<0.05)$.

\begin{tabular}{|c|c|c|c|c|}
\hline \multicolumn{5}{|c|}{ Animal 5} \\
\hline $\begin{array}{l}\text { Quantification } \\
\text { Method }\end{array}$ & $\begin{array}{c}\text { T1-normalized } \\
\text { MTRasym }\end{array}$ & AREX & LDA & $\begin{array}{c}\text { Multi-Lorentzian } \\
\text { Fitting }\end{array}$ \\
\hline MTRasym & $8.027 \times 10^{-2}$ & $1.839 \times 10^{-2}$ & $4.92 \times 10^{-34}$ & $2.008 \times 10^{-26}$ \\
\hline $\begin{array}{l}\text { T1-normalized } \\
\text { MTRasym }\end{array}$ & & $4.041 \times 10^{-1}$ & $4.409 \times 10^{-33}$ & $7.388 \times 10^{-26}$ \\
\hline AREX & & & $4.92 \times 10^{-34}$ & $2.008 \times 10^{-26}$ \\
\hline LDA & & & & $1.223 \times 10^{-1}$ \\
\hline
\end{tabular}

Supporting Table S2(f). $P$-values of Mann-Whitney $U$ test between the relative quantified APT effects (values) in the APT ischemic lesions of Animal 6 using the different quantification methods. Bold font indicates a significant difference $(P<0.05)$.

\begin{tabular}{|c|c|c|c|c|}
\hline \multicolumn{5}{|c|}{ Animal 6} \\
\hline $\begin{array}{l}\text { Quantification } \\
\text { Method }\end{array}$ & $\begin{array}{c}\text { T1-normalized } \\
\text { MTRasym }\end{array}$ & AREX & LDA & $\begin{array}{c}\text { Multi-Lorentzian } \\
\text { Fitting }\end{array}$ \\
\hline MTRasym & $3.079 \times 10^{-2}$ & $1.070 \times 10^{-2}$ & $2.952 \times 10^{-37}$ & $1.64 \times 10^{-40}$ \\
\hline $\begin{array}{l}\text { T1-normalized } \\
\text { MTRasym }\end{array}$ & & $5.685 \times 10^{-1}$ & $4.253 \times 10^{-37}$ & $2.532 \times 10^{-40}$ \\
\hline AREX & & & $8.922 \times 10^{-37}$ & $6.102 \times 10^{-40}$ \\
\hline LDA & & & & $1.239 \times 10^{-1}$ \\
\hline
\end{tabular}




\section{Ischemic Areas of $T_{1}$ and $T_{2}$ of Animals 1-6}

To investigate the ischemic area predictions of the $T_{1}$ and $T_{2}$ maps, the ischemic areas of the $T_{1}$ and $T_{2}$ maps were segmented via $\mathrm{K}$-means clustering. The automatically segmented ischemic areas are shown in Supporting Figure S3. The ADC ischemic lesion are overlaid on the $T_{1}$ and $T_{2}$ maps, outlined in red; the ischemic areas segmented from $T_{1}$ and $T_{2}$ are outlined in blue. It was observed that $T_{1}$ hyperintense areas coincided well with the $A D C$ lesions while the $T_{2}$ hypointense areas had comparatively smaller overlaps with the ADC lesions in most of the representative animals. These findings were consistent with previous publications as $T_{1}$ was found to be hyperintense in ischemic tissue, while $T_{2}$ had varying results in early stroke imaging $(20,31)$.

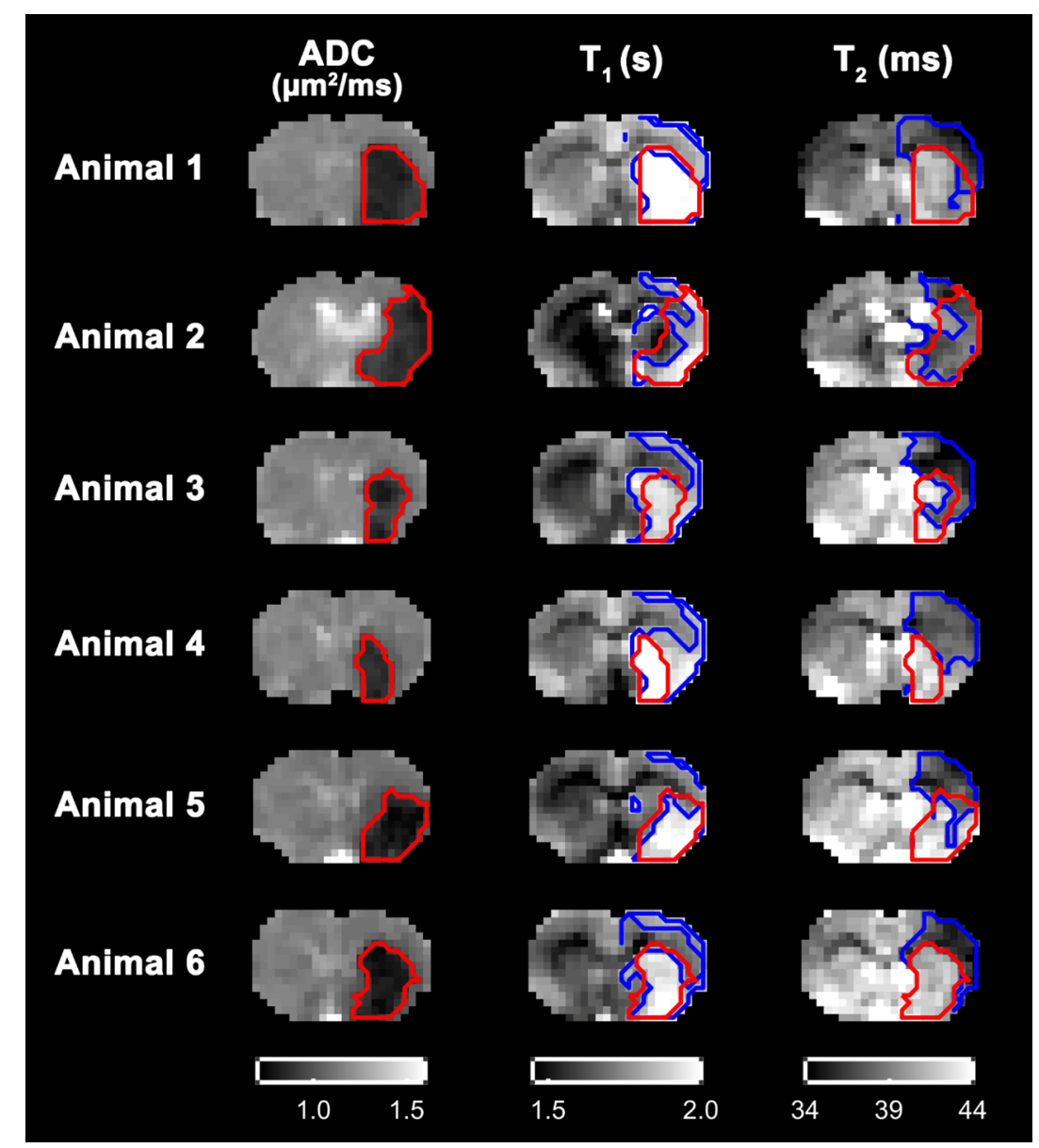

Supporting Figure S3. ADC $\left(\mu \mathrm{m}^{2} / \mathrm{ms}\right), T_{1}(\mathrm{~s})$, and $T_{2}(\mathrm{~ms})$ maps and corresponding ischemic areas of the six animals. For each animal, the ADC lesion is shown in red line, overlaid on all images; $T_{1}$ and $T_{2}$ predicted ischemic lesions are shown in blue lines. 


\section{Averaged Ischemic and Contralateral Z-Spectra of Animals 1 - 6}

Supporting Figure S4 below shows the averaged z-spectra within the ADC deficit area and contralateral area of Animals $1-6$. Although pulsed saturation was used in this study, the direct water saturation and CEST effect were found to approximate the Lorentzian lineshape well. As seen in the figure, the direct water saturation had a relatively narrow linewidth that fit the Lorentzian function. The CEST effects while having broader dips were also found to approximate the Lorentzian lineshape reasonably well.
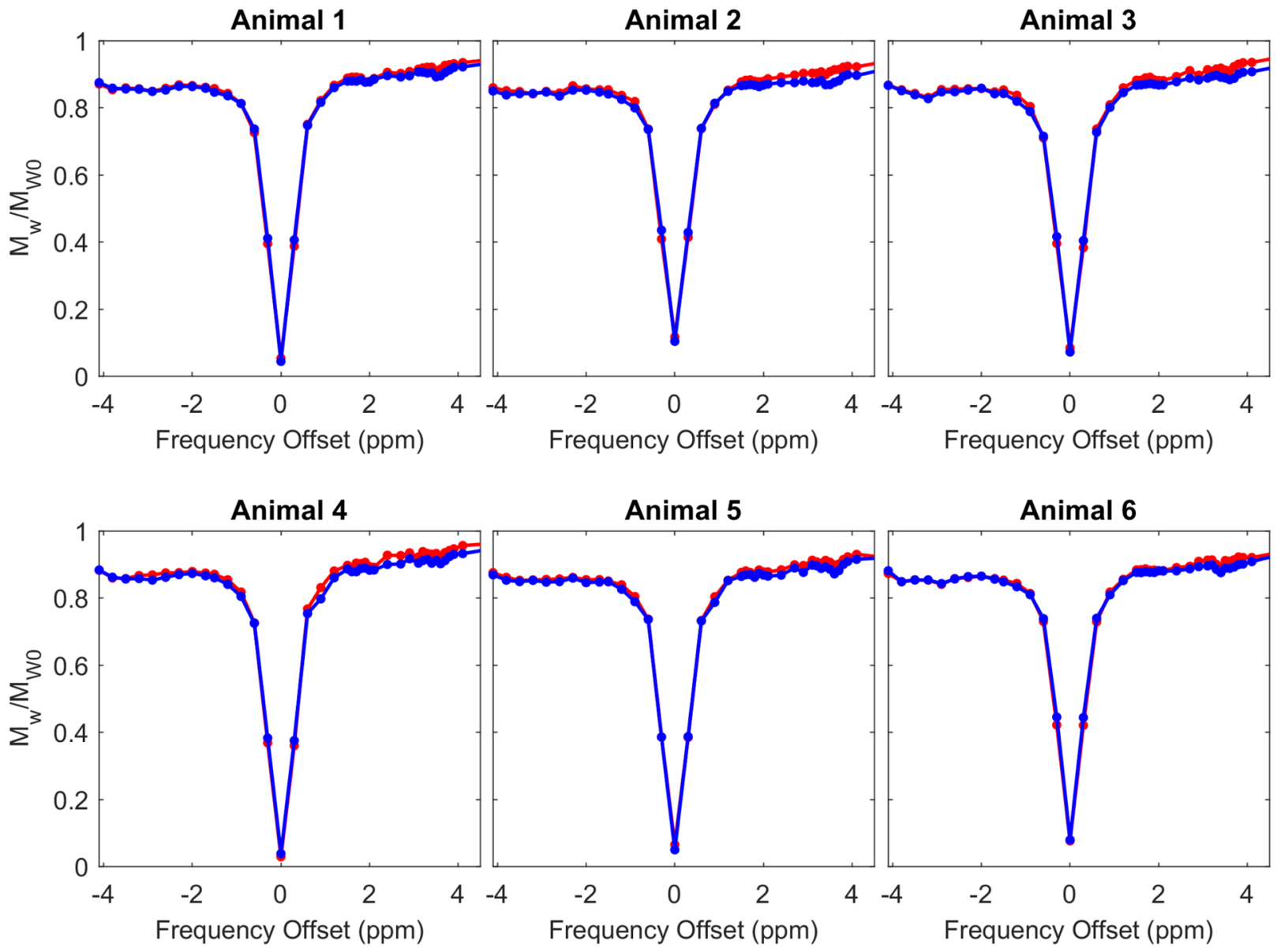

$\longrightarrow$ Ischemic Tissue $\longrightarrow$ Contralateral Tissue

Supporting Figure S4. Averaged z-spectra within the ADC ischemic (red) and contralateral (blue) areas of Animals $1-6$. 


\section{K-means Clusters of Quantified Values of APT Quantification Methods of}

Animals 1-6

Supporting Figure S5 shows the clusters of the quantified values of different APT quantification methods. The quantified APT values were automatically segmented using K-means clustering with two clusters and K-means ++ algorithm for center initialization seeding. From the figure, it can be observed that the K-means clustering algorithm was able to segment the quantified values into two clusters - the hypointense ischemic tissue (red) and non-ischemic tissue (blue). 

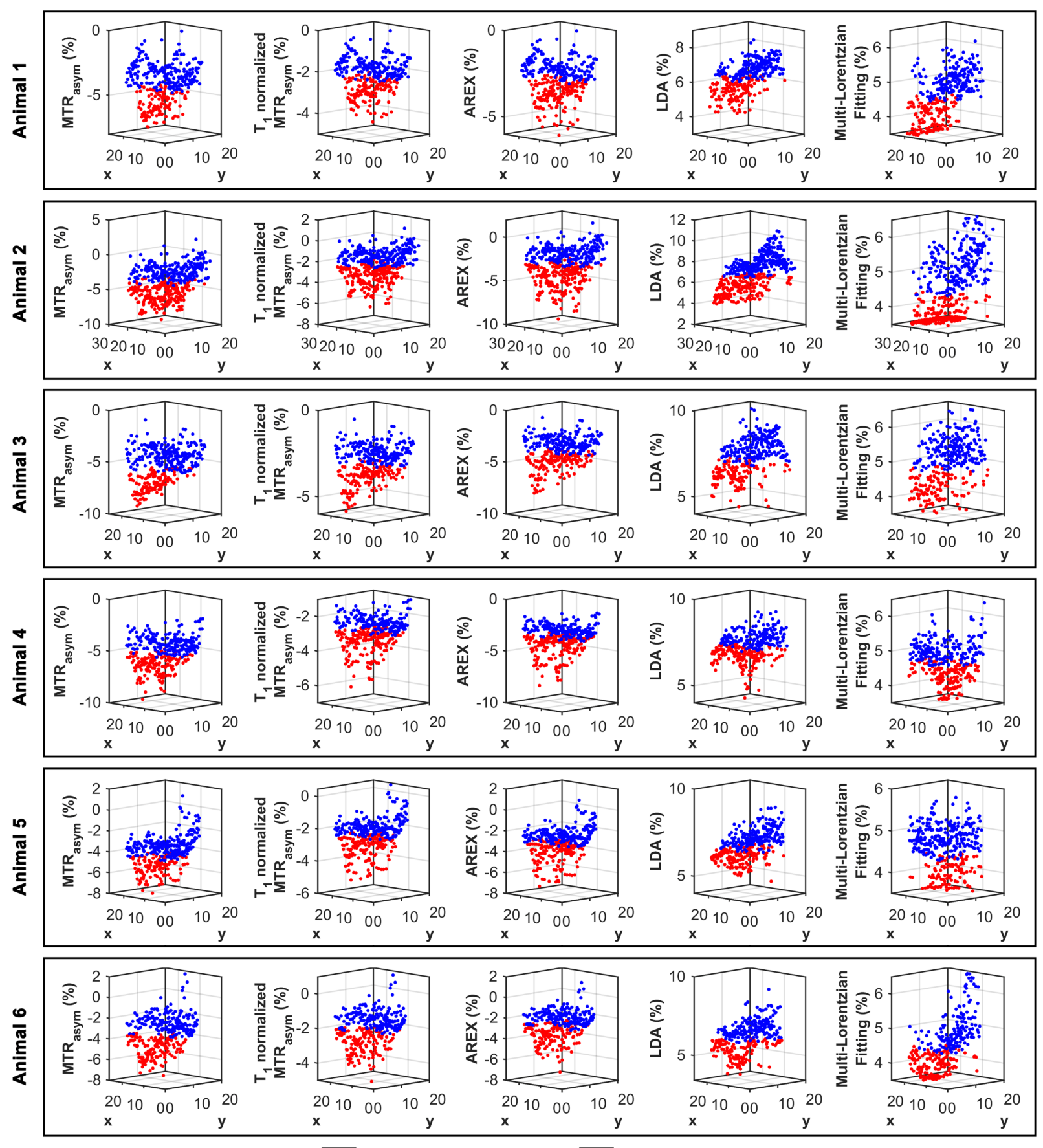

Ischemic Tissue

Non-ischemic Tissue

Supporting Figure S5. K-means clustering of the quantified APT effects of the different APT quantification methods. The quantified values were segmented into two clusters - ischemic tissue (red) and non-ischemic tissue (blue). 


\section{Changes in Quantified MTR asym( $3.5 \mathrm{ppm})$ During Ischemic Stroke}

Supporting Table S3 below summarizes the reported changes in quantified $\mathrm{MTR}_{\text {asym }}(\sim 3.5 \mathrm{ppm})$ due to ischemic stroke. A large majority of studies reported a decrease in the quantified APT effect during ischemia while some studies reported no changes or an increase in the quantified effect.

In the case of the two studies reporting APT effect to increase, for the animal stroke model study by Jin et al. (16), the animals were imaged 12 days post middle cerebral artery occlusion (MCAO); for the stroke patient study by $\mathrm{Yu}$ et al. (26), APT effect was observed to increase in ischemic tissue after 8 days post-treatment. It is worth noting that the increase in APT effect may be attributed to disease progression (time of imaging) instead of the experimental parameters or quantification methods.

Supporting Table S3. Reported changes in quantified MTR $\mathrm{Rsym}_{\mathrm{a}}(\sim 3.5 \mathrm{ppm})$ in ischemic stroke.

\begin{tabular}{|c|c|c|c|}
\hline Subject & Decrease & Increase & No Change \\
\hline $\begin{array}{l}\text { Animal } \\
\text { Model }\end{array}$ & $\begin{array}{l}\text { Zhou et al., } 2003 \text { (1); Zhou et al., } 2004 \text { (50); } \\
\text { Sun et al., } 2005 \text { (51); Sun et al., } 2007 \text { (2); } \\
\text { Sun et al., } 2007 \text { (52); Jokivarsi et al., } 2007 \\
\text { (13); } \\
\text { Jokivarsi et al, } 2010 \text { (24); Sun et al., } 2010(34) ; \\
\text { Sun et al., } 2011 \text { (33); Sun et al., } 2011(35) ; \\
\text { Sun et al., } 2011 \text { (37); Jin et al., } 2012(4) ; \\
\text { Sun et al., } 2012 \text { (3); Jin et al., } 2013(5) ; \\
\text { Zong et al., } 2014 \text { (8); Dai et al., } 2014(9)^{\dagger} ; \\
\text { Huang et al., } 2015 \text { (10); } \\
\text { Wang et al., } 2015(11) ; \\
\text { Guo et al., } 2016 \text { (12); Jin et al., } 2017(14) ; \\
\text { Wu et al., } 2018 \text { (17); Zu et al., } 2018(19) ; \\
\text { Lu et al., } 2018 \text { (20); Park et al., } 2019(22) ; \\
\text { Wang et al., } 2019 \text { (28); Sun et al., } 2020(31) ; \\
\text { Wu et al., } 2020 \text { (53) }\end{array}$ & $\begin{array}{c}\text { Jin et al., } 2017 \\
(16)^{\#}\end{array}$ & $\begin{array}{l}\text { Dai et al., } 2014 \\
(9)^{\dagger} ; \\
\text { Roussel et al., } \\
2018(21)\end{array}$ \\
\hline Patient & $\begin{array}{l}\text { Zhao et al., } 2011(36) \text {; Tietze et al., } 2014(6)^{*} \text {; } \\
\text { Tee et al., } 2014 \text { (7); Song et al., } 2017 \text { (18); Lin } \\
\text { et al., } 2018 \text { (23); Yu et al., } 2019(26)^{\Uparrow ;} \text {; Msayib } \\
\text { et al., } 2019 \text { (27); Lee et al., } 2020 \text { (30) }\end{array}$ & $\begin{array}{l}\text { Yu et al., } 2019 \\
(26)^{\Uparrow}\end{array}$ & $\begin{array}{l}\text { Tietze et al., } \\
2014(6)^{*} ; \\
\text { Heo et al., } \\
2017(15)^{\ddagger}\end{array}$ \\
\hline
\end{tabular}

* Contralateral tissue was found significantly different from ischemic core and at-risk tissue, but no significant differences were found between APT signal in final infarct and CNAWM.

† Contrast between ischemic and non-ischemic tissue diminishes depending on radio frequency power used.

‡ Ischemic APT effect was slightly hypointense compared to contralateral tissue, but not significantly different statistically.

\# Animals imaged 12 days after middle cerebral artery occlusion (MCAO). 
ฯ APT effect in ischemic lesion was higher than contralateral tissue after 8 days post-treatment.

The experimental parameters that corresponded to the observed changes in quantified $\operatorname{MTR}_{\text {asym }}(\sim 3.5 \mathrm{ppm})$ are listed in Supporting Table S4. Many different radio frequency (RF) saturation pulse parameters have been used among the studies, including continuous wave (CW), Gaussian, block, pseudocontinuous, Fermi, and Sinc-Gaussian pulses, and at different field strengths of $3 \mathrm{~T}, 4.7 \mathrm{~T}, 7 \mathrm{~T}, 9.4 \mathrm{~T}$, and $21.1 \mathrm{~T}$.

In summary, the saturation pulse parameters used at $4.7 \mathrm{~T}$ and $9.4 \mathrm{~T}$ reported thus far have yielded positive results. At $3 \mathrm{~T}$, the use of four $200 \mathrm{~ms}$ block pulses at $2 \mu \mathrm{T}$ amplitude should be avoided as no significant differences was observed between the DWI hyperintense and contralateral areas, although $\operatorname{MTR}_{\text {asym }}(\sim 3.5 \mathrm{ppm})$ was lower in ischemic tissue (15). For experiments investigating the delineation of ischemic injury zones at $3 \mathrm{~T}, 200 \mathrm{~ms} \mathrm{CW}$ saturation pulse of $0.5 \mu \mathrm{T}$ power should be avoided as these parameters did not produce significant differences between the core, penumbra, and oligemia (6).

At $7 \mathrm{~T}$, when Gaussian pulse of 4096 saturation step, $15 \mathrm{~ms}$ pulse width is used, the saturation power should be less than $1.57 \mu \mathrm{T}$ to observe contrast between ischemic and normal tissues (9).

As for $21.1 \mathrm{~T}$, only one study has investigated the use of this high field strength using a train of 400 Gaussian pulses of $10 \mathrm{~ms}$ duration at low power of $1.5 \mu \mathrm{T}$ and high power of $3.5 \mu \mathrm{T}$. Both saturation powers did not produce significant differences between the ischemic and normal tissues. However, this should not rule out 21.1 $\mathrm{T}$ as a useful field strength for ischemic stroke imaging as limited work has been done at this field strength, and further investigations are needed.

Supporting Table S4. Experimental parameters of the studies reporting $\operatorname{MTR}_{\text {asym }}(\sim 3.5 \mathrm{ppm})$ results.

\begin{tabular}{|c|c|c|c|}
\hline Reference & $\begin{array}{c}\text { Scanner } \\
\text { Field } \\
\text { Strength }\end{array}$ & \multicolumn{1}{|c|}{$\begin{array}{c}\text { Radio Frequency (RF) } \\
\text { Saturation Pulse Parameters }\end{array}$} & ROI(s) Investigated \\
\hline \multicolumn{1}{|c|}{ Decrease } \\
$\begin{array}{c}\text { Zhou et al., } \\
2003(1)\end{array}$ & $4.7 \mathrm{~T}$ & $\begin{array}{l}\text { A train of } 400 \text { Gaussian pulses } \\
\text { (length } 6.6 \mathrm{~ms}, \text { flip angle } 180^{\circ}, \\
\text { delay } 3.4 \mathrm{~ms}, \text { total saturation } \\
\text { duration } 4 \mathrm{~s}, \text { average RF power of } \\
50 \mathrm{~Hz}) .\end{array}$ & $\begin{array}{l}\text { Ipsilateral and contralateral } \\
\text { caudate. }\end{array}$ \\
\hline
\end{tabular}




\begin{tabular}{|c|c|c|c|}
\hline $\begin{array}{l}\text { Zhou et al., } \\
2004 \text { (50) }\end{array}$ & $4.7 \mathrm{~T}$ & $\begin{array}{l}\text { A train of } 400 \text { Gaussian pulses } \\
\text { (length } 6.6 \mathrm{~ms} \text {, flip angle } 180^{\circ} \text {, } \\
\text { delay } 3.4 \mathrm{~ms} \text {, total saturation } \\
\text { duration } 4 \mathrm{~s} \text {, average RF power of } \\
\sim 50 \mathrm{~Hz} \text { ). }\end{array}$ & $\begin{array}{l}\text { Caudate nucleus, cortex near } \\
\text { the caudate, and cerebellum. }\end{array}$ \\
\hline $\begin{array}{l}\text { Sun et al., } \\
2005(51)\end{array}$ & $4.7 \mathrm{~T}$ & $\begin{array}{l}\text { Continuous saturation RF pulse of } \\
\text { a power of } 1.5 \mu \mathrm{T} \text { applied for } 4 \mathrm{~s} \text {. }\end{array}$ & $\begin{array}{l}\text { No particular ROI; changes } \\
\text { observed visually. }\end{array}$ \\
\hline $\begin{array}{l}\text { Sun et al., } \\
2007(2)\end{array}$ & $4.7 \mathrm{~T}$ & $\begin{array}{l}4 \mathrm{~s} C W \text { pulse was applied; the } \\
\text { irradiation power was varied }(0.25 \text {, } \\
0.5,0.75,1,1.5,2 \text {, and } 3 \mu \mathrm{T}) \text {. }\end{array}$ & $\begin{array}{l}\text { CBF hypoperfused and } \\
\text { contralateral areas. }\end{array}$ \\
\hline $\begin{array}{l}\text { Sun et al., } \\
2007(52)\end{array}$ & $4.7 \mathrm{~T}$ & $\begin{array}{l}\text { MT irradiation pulses of } 1.5 \mu \mathrm{T} \\
\text { lasting for } 4 \mathrm{~s} \text {. }\end{array}$ & $\begin{array}{l}\text { APT deficit area defined by } \\
\text { thresholding, as well as DWI } \\
\text { lesion and contralateral area. }\end{array}$ \\
\hline $\begin{array}{l}\text { Jokivarsi et } \\
\text { al., } 2007 \\
\quad(13)\end{array}$ & $4.7 \mathrm{~T}$ & $\begin{array}{l}\text { A train of } 6.6 \mathrm{~ms} \text { long } 180^{\circ} \\
\text { Gaussian pulses }\left(\gamma B_{1}=50 \mathrm{~Hz}\right) \text { with } \\
\text { an interpulse delay of } 3.4 \mathrm{~ms} \text { for } \\
\text { 4s. }\end{array}$ & $\begin{array}{l}\text { Ipsilateral and contralateral } \\
\text { hemispheres, as well as ADC } \\
\text { deficit area and contralateral } \\
\text { areas. }\end{array}$ \\
\hline $\begin{array}{l}\text { Jokivarsi et } \\
\text { al, } 2010 \\
(24)\end{array}$ & $4.7 \mathrm{~T}$ & $\begin{array}{l}5 \mathrm{~s} \text { train of } 2.0 \mathrm{~ms} \text { long } 180^{\circ} \\
\text { Gaussian pulses }\left(\mathrm{\gamma} B_{1}=50 \mathrm{~Hz}\right) \text {, } \\
\text { without interpulse delay. }\end{array}$ & $\begin{array}{l}\text { Ipsilateral and contralateral } \\
\text { striatum, insular cortex, and } \\
\text { cortex. }\end{array}$ \\
\hline $\begin{array}{l}\text { Sun et al., } \\
2010(34)\end{array}$ & $4.7 \mathrm{~T}$ & $\begin{array}{l}\text { CW saturation of } 0.75 \mu \mathrm{T} \\
\text { amplitude. }\end{array}$ & $\begin{array}{l}\text { No particular ROI; changes } \\
\text { observed visually. }\end{array}$ \\
\hline $\begin{array}{l}\text { Sun et al., } \\
2011(33)\end{array}$ & $4.7 \mathrm{~T}$ & $\begin{array}{l}\text { 1. CW RF irradiation of } 3000 \mathrm{~ms} \\
\text { duration and } B_{1}=0.75 \mu \mathrm{T} \text {. } \\
\text { 2. RF irradiation of primary RF } \\
\text { irradiation time of } 3000 \mathrm{~ms} \text {, } \\
\text { secondary irradiation pulse } \\
\text { varied from } 500 \mathrm{~ms} \text {. }\end{array}$ & $\begin{array}{l}\text { ADC deficit area and } \\
\text { contralateral areas. }\end{array}$ \\
\hline $\begin{array}{l}\text { Sun et al., } \\
2011(35)\end{array}$ & $4.7 \mathrm{~T}$ & $\begin{array}{l}\text { 1. CW saturation of } 0.75 \mu \mathrm{T} \\
\text { amplitude and saturation time } \\
1 / \text { saturation time } 2=4500 / 500 \\
\text { ms; } \\
\text { 2. Gaussian pulse with } 180^{\circ} \text { flip } \\
\text { angle, } 15 \mathrm{~ms} \text { pulse duration, } \\
50 \% \text { duty cycle and saturation } \\
\text { time } 1 / \text { saturation time } 2= \\
4500 / 500 \mathrm{~ms} \text {. }\end{array}$ & $\begin{array}{l}\text { ADC hypointense area in the } \\
\text { striatum. }\end{array}$ \\
\hline $\begin{array}{l}\text { Sun et al., } \\
2011(37) ; \\
\text { Sun et al., } \\
2012(3) ; \\
\text { Wang et al., } \\
2019(28)\end{array}$ & $4.7 \mathrm{~T}$ & $\begin{array}{l}\text { RF irradiation of primary saturation } \\
\text { duration of } 4500 \mathrm{~ms} \text {, secondary } \\
\text { saturation duration of } 500 \mathrm{~ms} \text {, and } \\
\text { RF power of } 0.75 \mu \mathrm{T} \text {. }\end{array}$ & $\begin{array}{l}\text { ROI within ipsilateral side in } \\
\text { the striatum and contralateral } \\
\text { ROI. }\end{array}$ \\
\hline
\end{tabular}




\begin{tabular}{|c|c|c|c|}
\hline $\begin{array}{l}\text { Zhao et al., } \\
2011 \text { (36) }\end{array}$ & $3 \mathrm{~T}$ & $\begin{array}{l}\mathrm{CW} \text { saturation pulse with duration } \\
\text { of } 500 \mathrm{~ms} \text {, and saturation powers } \\
\text { of } 1,2 \text {, and } 3 \mu \mathrm{T} \text {. }\end{array}$ & $\begin{array}{l}\mathrm{T}_{2 \mathrm{w}} \text { and FLAIR abnormality } \\
\text { area and contralateral normal- } \\
\text { appearing white matter } \\
\text { (CNAWM). }\end{array}$ \\
\hline $\begin{array}{l}\text { Jin et al., } \\
2012(4)\end{array}$ & $9.4 \mathrm{~T}$ & Irradiation power of $63 \mathrm{~Hz}$ for $3 \mathrm{~s}$. & $\begin{array}{l}\text { APT lesion and contralateral } \\
\text { areas. }\end{array}$ \\
\hline $\begin{array}{l}\text { Jin et al., } \\
2013(5)\end{array}$ & $9.4 \mathrm{~T}$ & $\begin{array}{l}\mathrm{CW} \text { saturation of } 1.25 \mu \mathrm{T} \text { power } \\
\text { and saturation time of } 3 \mathrm{~s} \text {. }\end{array}$ & $\begin{array}{l}\text { ROls within the ipsilateral and } \\
\text { contralateral caudate-putamen } \\
\text { (CPu) and white matter (WM) } \\
\text { based on DWI. }\end{array}$ \\
\hline $\begin{array}{l}\text { Tietze et } \\
\text { al., } 2014(6)\end{array}$ & $3 \mathrm{~T}$ & $\begin{array}{l}\text { Block pulse of } 0.5 \mu \mathrm{T} \text { power and } \\
200 \text { ms duration. }\end{array}$ & $\begin{array}{l}\text { Hypointense acute ADC, } \\
\text { prolonged relative TTP, and } \\
\text { hyperintense follow-up FLAIR } \\
\text { areas, and CNAWM. }\end{array}$ \\
\hline $\begin{array}{l}\text { Zong et al., } \\
2014(8)\end{array}$ & $9.4 \mathrm{~T}$ & $\begin{array}{l}\mathrm{CW} \text { pulse of } 64 \mathrm{~Hz} \text { power and } 3 \mathrm{~s} \\
\text { duration. }\end{array}$ & $\begin{array}{l}\text { ROI based on } A D C \text { map and } \\
\text { contralateral area. }\end{array}$ \\
\hline $\begin{array}{l}\text { Dai et al., } \\
2014(9)\end{array}$ & $7 \mathrm{~T}$ & $\begin{array}{l}\text { 1. Number of saturation steps } \\
\text { was varied from } 64,128,256 \text {, } \\
512,1024 \text {, to } 2048 \text {; with } \\
\text { saturation power } 0.39 \mu \mathrm{T} \text { and } \\
\text { saturation duration } 15 \mathrm{~ms} \text {. } \\
\text { 2. Saturation power (gauss pulse, } \\
15 \mathrm{~ms} \text { pulse width) was varied } \\
\text { from } 0.39 \mu \mathrm{T} \text { to } 1.57 \mu \mathrm{T} \text { with } \\
\text { intervals of } 0.19 \mu \mathrm{T} \text { with } \\
\text { number of saturation steps }= \\
4096 \text {, and flip angle }=5^{\circ} \text {. } \\
\text { 3. Flip angle was varied from } 5^{\circ} \text { to } \\
20^{\circ} \text { with intervals of } 5^{\circ}\left(B_{1} 0.39\right. \\
\mu \mathrm{T} \text {, step }=4096) \text {. }\end{array}$ & $\begin{array}{l}\text { ROI were manually drawn on } \\
\text { the ischemic lesions and } \\
\text { contralateral normal regions by } \\
\text { three expert radiologists based } \\
\text { on the APT images. }\end{array}$ \\
\hline $\begin{array}{l}\text { Tee et al., } \\
2014(7)\end{array}$ & $3 \mathrm{~T}$ & $\begin{array}{l}50 \text { Gaussian pulses with flip angle } \\
\text { of } 184^{\circ} \text { and duration of } 20 \text { ms with } \\
20 \mathrm{~ms} \text { spacing for } 2 \mathrm{~s} \text {, equivalent } \\
\text { to } 0.55 \mu \mathrm{T} \text { average power. }\end{array}$ & $\begin{array}{l}\text { Infarct core mask and mirror } \\
\text { mask were manually drawn by } \\
\text { a clinician based on DWI data. }\end{array}$ \\
\hline $\begin{array}{l}\text { Huang et } \\
\text { al., } 2015 \\
\quad(10)\end{array}$ & $7 \mathrm{~T}$ & $\begin{array}{l}\text { Presaturation time of } 20 \mathrm{~ms} \text { and } \\
\text { flip angle of } \sim 180^{\circ} .\end{array}$ & $\begin{array}{l}\text { APT deficit area and normal- } \\
\text { appearing area. }\end{array}$ \\
\hline $\begin{array}{l}\text { Wang et al., } \\
2015 \text { (11) }\end{array}$ & $4.7 \mathrm{~T}$ & Saturation power of $1.3 \mu \mathrm{T}$ for $4 \mathrm{~s}$. & $\begin{array}{l}\text { ROIs based on ADC map } \\
\text { abnormalities and contralateral } \\
\text { normal-appearing tissue. }\end{array}$ \\
\hline $\begin{array}{l}\text { Guo et al., } \\
2016(12)\end{array}$ & $4.7 \mathrm{~T}$ & $\begin{array}{l}\text { Primary RF saturation duration of } \\
4500 \mathrm{~ms} \text {, secondary RF saturation } \\
\text { duration of } 500 \mathrm{~ms} \text {, for an RF } \\
\text { amplitude of } 0.75 \mu \mathrm{T} \text {. }\end{array}$ & $\begin{array}{l}\text { Hypointense APT effect in } \\
\text { ipsilateral brain, and } \\
\text { contralateral intact tissue. }\end{array}$ \\
\hline
\end{tabular}




\begin{tabular}{|c|c|c|c|}
\hline $\begin{array}{l}\text { Jin et al., } \\
2017(14)\end{array}$ & $9.4 \mathrm{~T}$ & $\begin{array}{l}\mathrm{CW} \text { saturation of } 3.5 \text { s duration, } 34 \\
\mathrm{~Hz} \text { and } 42 \mathrm{~Hz} \text { power. }\end{array}$ & $\begin{array}{l}\text { ADC deficit area defined by } \\
\text { thresholding and contralateral } \\
\text { area. }\end{array}$ \\
\hline $\begin{array}{l}\text { Wu et al., } \\
2018(17)\end{array}$ & $4.7 \mathrm{~T}$ & $\begin{array}{l}\text { Primary RF saturation duration of } \\
2500 \mathrm{~ms} \text {, and secondary duration } \\
\text { of } 500 \mathrm{~ms} \text {, under two RF irradiation } \\
\text { amplitudes of } 1.5 \text { and } 0.75 \mu \mathrm{T} \text {. }\end{array}$ & $\begin{array}{l}\text { ADC and } \mathrm{CBF} \text { deficit, } \\
\mathrm{ADC} / \mathrm{CBF} \text { mismatch, and } \\
\text { contralateral areas. }\end{array}$ \\
\hline $\begin{array}{l}\text { Song et al., } \\
2017 \text { (18) }\end{array}$ & $3 \mathrm{~T}$ & Not stated. & $\begin{array}{l}\text { Five ROls within the DWI } \\
\text { lesions and one contralateral } \\
\text { ROI. }\end{array}$ \\
\hline $\begin{array}{l}\text { Zu et al., } \\
2018(19)\end{array}$ & $7 \mathrm{~T}$ & $\begin{array}{l}\text { Rectangular irradiation pulse with } \\
\text { amplitude of } 1 \mu \mathrm{T} \text { and duration of } 5 \\
\mathrm{~s} \text {. }\end{array}$ & $\begin{array}{l}\Delta \mathrm{R}_{1 \rho} \text { hyperintense areas and } \\
\text { contralateral areas. }\end{array}$ \\
\hline $\begin{array}{l}\text { Lu et al., } \\
2018(20)\end{array}$ & $4.7 \mathrm{~T}$ & $\begin{array}{l}\text { Primary RF saturation time of } 3000 \\
\mathrm{~ms} \text {, secondary irradiation of } 500 \\
\mathrm{~ms} \text {, and power of } 0.75 \mu \mathrm{T} \text {. }\end{array}$ & $\begin{array}{l}\text { APT hypointense area and } \\
\text { contralateral normal tissue. }\end{array}$ \\
\hline $\begin{array}{l}\text { Park et al., } \\
2019(22)\end{array}$ & $7 \mathrm{~T}$ & Not stated. & $\begin{array}{l}\text { CBF perfusion deficit area } \\
\text { manually drawn by } \\
\text { neuroradiologists and } \\
\text { contralateral area, as well as } \\
\text { APT deficit area defined by } \\
\text { thresholding. }\end{array}$ \\
\hline $\begin{array}{l}\text { Lin et al., } \\
2018(23)\end{array}$ & $3 \mathrm{~T}$ & $\begin{array}{l}\text { Fermi pulses with } 40 \text { ms width, flip } \\
\text { angle of } 340^{\circ} \text {, duty cycle of } 50 \% \\
\text { for RF irradiation power of } 1 \mu \mathrm{T} \text {. }\end{array}$ & $\begin{array}{l}\text { Three ROIs within the DWI } \\
\text { lesions and three contralateral } \\
\text { ROI. }\end{array}$ \\
\hline $\begin{array}{l}\text { Yu et al., } \\
2019(26)\end{array}$ & $3 \mathrm{~T}$ & $\begin{array}{l}\text { Pseudocontinuous wave, off- } \\
\text { resonance RF irradiation of } 800 \\
\text { ms saturation duration and } 2 \mu \mathrm{T} \\
\text { power level. }\end{array}$ & $\begin{array}{l}\text { Small ROls within the APT } \\
\text { lesions and one contralateral } \\
\text { ROI manually drawn by } \\
\text { radiologist. }\end{array}$ \\
\hline $\begin{array}{l}\text { Msayib et } \\
\text { al., } 2019 \\
\quad(27)\end{array}$ & $3 \mathrm{~T}$ & $\begin{array}{l}50 \text { Gaussian pulses with flip angle } \\
\text { of } 184^{\circ} \text { and duration of } 20 \text { ms with } \\
20 \mathrm{~ms} \text { spacing for } 2 \mathrm{~s} \text {, equivalent } \\
\text { to } 0.55 \mu \mathrm{T} \text { average power. }\end{array}$ & $\begin{array}{l}\text { Infarct at presentation was } \\
\text { defined as ADC deficit by } \\
\text { thresholding. Final infarct was } \\
\text { defined on 1-week FLAIR, or if } \\
\text { not available, } b=1000 \mathrm{DWI} \text { at } \\
24 \text { h. Perfusion deficit was } \\
\text { defined using thresholding of } \\
\text { CBF map. From these } \\
\text { definitions, 3 ROls were } \\
\text { defined: } \\
\text { 1. Ischemic core: present in } \\
\text { both infarct at presentation } \\
\text { and final infarct. } \\
\text { 2. Infarct growth: Within final } \\
\text { infarct, but not within } \\
\text { presenting infarct. } \\
\text { 3. Oligemia: Present in }\end{array}$ \\
\hline
\end{tabular}




\begin{tabular}{|c|c|c|c|}
\hline & & & $\begin{array}{l}\text { perfusion deficit, but not } \\
\text { final infarct. } \\
\text { 4. Mirrored contralateral } \\
\text { mask. }\end{array}$ \\
\hline $\begin{array}{l}\text { Lee et al., } \\
2020(30)\end{array}$ & $3 \mathrm{~T}$ & $\begin{array}{l}\text { Sinc-Gaussian pulse of } 1.2 \mu \mathrm{T} \\
\text { power and } 4 \mathrm{~s} \text { pulse duration ( } 50 \\
\mathrm{~ms} \times 80 \text { sub-pulse elements). }\end{array}$ & $\begin{array}{l}\text { T2 hyperintense lesion drawn } \\
\text { by neuroradiologist. }\end{array}$ \\
\hline $\begin{array}{l}\text { Sun et al., } \\
2020(31)\end{array}$ & $4.7 \mathrm{~T}$ & $\begin{array}{l}\text { 1. CW saturation with primary } \\
\text { saturation time of } 3000 \text { ms and } \\
\text { secondary saturation time of } \\
500 \text { ms and } 0.75 \mu \mathrm{T} \text { amplitude. } \\
\text { 2. Gaussian pulse train of flip } \\
\text { angle } 180^{\circ} \text { and } 50 \% \text { duty } \\
\text { cycle. The pulse duration and } \\
\text { flip angle were varied for } \\
\text { optimization. }\end{array}$ & $\begin{array}{l}\text { ADC lesion defined via K- } \\
\text { means clustering algorithm, } \\
\text { and contralateral area. }\end{array}$ \\
\hline $\begin{array}{l}\text { Wu et al., } \\
2020(53)\end{array}$ & $4.7 \mathrm{~T}$ & $\begin{array}{l}\text { Primary saturation time of } 3000 \\
\text { ms, secondary saturation time of } \\
500 \mathrm{~ms} \text {, and power of } 0.75 \mu \mathrm{T} \text {. }\end{array}$ & $\begin{array}{l}\text { Diffusion lesion defined using } \\
\text { K-means clustering and } \\
\text { contralateral ROI. }\end{array}$ \\
\hline \multicolumn{4}{|c|}{ Increase } \\
\hline $\begin{array}{l}\text { Jin et al., } \\
2017(16)\end{array}$ & $9.4 \mathrm{~T}$ & $\begin{array}{l}\text { Saturation pulse with a power of } \\
220 \mathrm{~Hz} \text { and a duration of } 2 \mathrm{~s} \text {. }\end{array}$ & $\begin{array}{l}\text { Tissue volume loss was } \\
\text { defined based on hyperintense } \\
\text { signal on } T_{2} \text {-weighted images } \\
\text { via thresholding. }\end{array}$ \\
\hline $\begin{array}{l}\text { Yu et al., } \\
2019(26)\end{array}$ & $3 \mathrm{~T}$ & $\begin{array}{l}\text { Pseudocontinuous wave, off- } \\
\text { resonance RF irradiation of } 800 \\
\text { ms saturation duration and } 2 \mu \mathrm{T} \\
\text { power level. }\end{array}$ & $\begin{array}{l}\text { Small ROIs within the APT } \\
\text { lesions and one contralateral } \\
\text { ROI manually drawn by } \\
\text { radiologist. }\end{array}$ \\
\hline \multicolumn{4}{|c|}{ No Change } \\
\hline $\begin{array}{l}\text { Dai et al., } \\
2014(9)\end{array}$ & $7 \mathrm{~T}$ & $\begin{array}{l}\text { 1. Number of saturation steps } \\
\text { was varied from } 64,128,256 \text {, } \\
512,1024 \text {, to } 2048 \text {; with } \\
\text { saturation power } 0.39 \mu \mathrm{T} \text { and } \\
\text { saturation duration } 15 \mathrm{~ms} \text {. } \\
\text { 2. Saturation power (gauss pulse, } \\
15 \mathrm{~ms} \text { pulse width) was varied } \\
\text { from } 0.39 \mu \mathrm{T} \text { to } 1.57 \mu \mathrm{T} \text { with } \\
\text { intervals of } 0.19 \mu \mathrm{T} \text { with } \\
\text { number of saturation steps }= \\
4096 \text {, and flip angle }=5^{\circ} \text {. } \\
\text { 3. Flip angle was varied from } 5^{\circ} \text { to } \\
20^{\circ} \text { with intervals of } 5^{\circ}\left(B_{1} 0.39\right. \\
\mu \mathrm{T}, \text { step }=4096) \text {. }\end{array}$ & $\begin{array}{l}\text { ROI were manually drawn on } \\
\text { the ischemic lesions and } \\
\text { contralateral normal regions by } \\
\text { three expert radiologists based } \\
\text { on the APT images. }\end{array}$ \\
\hline $\begin{array}{c}\text { Tietze et } \\
\text { al., } 2014(6)\end{array}$ & $3 T$ & $\begin{array}{l}\text { Block pulse of } 0.5 \mu \mathrm{T} \text { power and } \\
200 \text { ms duration. }\end{array}$ & $\begin{array}{l}\text { Hypointense acute } \mathrm{ADC} \text {, } \\
\text { prolonged relative TTP, and }\end{array}$ \\
\hline
\end{tabular}




\begin{tabular}{|c|c|l|l|}
\hline & & $\begin{array}{l}\text { hyperintense follow-up FLAIR } \\
\text { areas, and CNAWM. }\end{array}$ \\
\hline $\begin{array}{c}\text { Heo et al., } \\
2017(15)\end{array}$ & $3 \mathrm{~T}$ & $\begin{array}{l}\text { Four block RF saturation pulses } \\
\text { with duration of } 200 \mathrm{~ms} \text { (total } \\
\text { saturation time of } 800 \mathrm{~ms} \text { ) and } \\
\text { amplitude of } 2 \mu \mathrm{T} .\end{array}$ & $\begin{array}{l}\text { DWI hyperintense area and } \\
\text { contralateral area. }\end{array}$ \\
\hline $\begin{array}{c}\text { Roussel et } \\
\text { al., 2018 } \\
(21)\end{array}$ & $21.1 \mathrm{~T}$ & $\begin{array}{l}\text { A train of } 400 \text { Gaussian pulses of } \\
10 \mathrm{~ms} \text { duration and power of } 3.5 \\
\text { and } 1.5 \mu \mathrm{T} .\end{array}$ & $\begin{array}{l}\text { ROls manually segmented } \\
\text { from APT image highlighting } \\
\text { normal and ischemic tissue. }\end{array}$ \\
\hline
\end{tabular}




\section{References}

1. Zhou J, Payen J-F, Wilson DA, Traystman RJ, van Zijl PCM. Using the amide proton signals of intracellular proteins and peptides to detect pH effects in MRI. Nat. Med. 2003;9:1085-90 doi: 10.1038/nm907.

2. Sun PZ, Zhou J, Huang J, Van Zijl P. Simplified quantitative description of amide proton transfer (APT) imaging during acute ischemia. Magn. Reson. Med. 2007 doi: $10.1002 / \mathrm{mrm} .21151$

3. Sun PZ, Wang E, Cheung JS. Imaging acute ischemic tissue acidosis with $\mathrm{pH}$-sensitive endogenous amide proton transfer (APT) MRI-Correction of tissue relaxation and concomitant RF irradiation effects toward mapping quantitative cerebral tissue $\mathrm{pH}$. Neuroimage 2012 doi: 10.1016/j.neuroimage.2011.11.091.

4. Jin T, Wang P, Zong X, Kim SG. Magnetic resonance imaging of the Amine-Proton EXchange (APEX) dependent contrast. Neuroimage 2012 doi: 10.1016/j.neuroimage.2011.08.014.

5. Jin T, Wang P, Zong X, Kim SG. MR imaging of the amide-proton transfer effect and the $\mathrm{pH}$-insensitive nuclear overhauser effect at 9.4 T. Magn. Reson. Med. 2013 doi: $10.1002 / \mathrm{mrm} .24315$.

6. Tietze A, Blicher J, Mikkelsen IK, et al. Assessment of ischemic penumbra in patients with hyperacute stroke using amide proton transfer (APT) chemical exchange saturation transfer (CEST) MRI. NMR Biomed. 2014;27:163-174 doi: 10.1002/nbm.3048.

7. Tee YK, Harston GWJ, Blockley N, et al. Comparing different analysis methods for quantifying the MRI amide proton transfer (APT) effect in hyperacute stroke patients. NMR Biomed. 2014;27:1019-1029 doi: 10.1002/nbm.3147.

8. Zong X, Wang P, Kim SG, Jin T. Sensitivity and source of amine-proton exchange and amide-proton transfer magnetic resonance imaging in cerebral ischemia. Magn. Reson. Med. 2014;71:118-132 doi: 10.1002/mrm.24639.

9. Dai Z, Ji J, Xiao G, et al. Magnetization transfer prepared gradient echo MRI for CEST imaging. PLoS One 2014;9 doi: 10.1371/journal.pone.0112219.

10. Huang D, Li S, Dai Z, Shen Z, Yan G, Wu R. Novel gradient echo sequence-based amide proton transfer magnetic resonance imaging in hyperacute cerebral infarction. Mol. Med. Rep. 2015;11:3279-3284 doi: 10.3892/mmr.2015.3165.

11. Wang $M$, Hong $X$, Chang CF, et al. Simultaneous detection and separation of hyperacute intracerebral hemorrhage and cerebral ischemia using amide proton transfer MRI. Magn. Reson. Med. 2015;74:42-50 doi: 10.1002/mrm.25690.

12. Guo Y, Zhou IY, Chan ST, et al. pH-sensitive MRI demarcates graded tissue acidification during acute stroke - $\mathrm{pH}$ specificity enhancement with magnetization transfer and relaxation-normalized amide proton transfer (APT) MRI. Neuroimage 2016 doi: 10.1016/j.neuroimage.2016.07.025.

13. Jokivarsi KT, Gröhn HI, Gröhn OH, Kauppinen RA. Proton transfer ratio, lactate, and intracellular pH in acute cerebral ischemia. Magn. Reson. Med. 2007 doi: $10.1002 / \mathrm{mrm} .21181$.

14. Jin $T$, Wang $P$, Jin T, Kim SG, Kim SG. Enhancing sensitivity of pH-weighted MRI with combination of amide and guanidyl CEST. Neuroimage 2017 doi: 10.1016/j.neuroimage.2017.06.007.

15. Heo HY, Zhang Y, Burton TM, et al. Improving the detection sensitivity of pH-weighted 
amide proton transfer MRI in acute stroke patients using extrapolated semisolid magnetization transfer reference signals. Magn. Reson. Med. 2017;78:871-880 doi: 10.1002/mrm.26799.

16. Jin T, Nicholls FJ, Crum WR, Ghuman H, Badylak SF, Modo M. Diamagnetic chemical exchange saturation transfer (diaCEST) affords magnetic resonance imaging of extracellular matrix hydrogel implantation in a rat model of stroke. Biomaterials 2017;113:176-190 doi: 10.1016/j.biomaterials.2016.10.043.

17. Wu Y, Zhou IY, Lu D, et al. pH-sensitive amide proton transfer effect dominates the magnetization transfer asymmetry contrast during acute ischemia-quantification of multipool contribution to in vivo CEST MRI. Magn. Reson. Med. 2018;79:1602-1608 doi: $10.1002 / \mathrm{mrm} .26829$.

18. Song G, Li C, Luo X, et al. Evolution of cerebral ischemia assessed by amide proton transfer-weighted MRI. Front. Neurol. 2017;8 doi: 10.3389/fneur.2017.00067.

19. Zu Z, Afzal A, Li H, Xie J, Gore JC. Spin-lock imaging of early tissue pH changes in ischemic rat brain. NMR Biomed. 2018 doi: 10.1002/nbm.3893.

20. Lu D, Jiang Y, Ji Y, et al. Evaluation of diffusion kurtosis imaging of stroke lesion with hemodynamic and metabolic MRI in a rodent model of acute stroke. Am. J. Roentgenol. 2018 doi: 10.2214/AJR.17.19134.

21. Roussel T, Rosenberg JT, Grant SC, Frydman L. Brain investigations of rodent disease models by chemical exchange saturation transfer at 21.1 T. NMR Biomed. 2018;31:1-13 doi: 10.1002/nbm.3995.

22. Park JE, Jung SC, Kim HS, et al. Amide proton transfer-weighted MRI can detect tissue acidosis and monitor recovery in a transient middle cerebral artery occlusion model compared with a permanent occlusion model in rats. Eur. Radiol. 2019 doi: 10.1007/s00330018-5964-3.

23. Lin G, Zhuang C, Shen Z, et al. APT weighted MRI as an effective imaging protocol to predict clinical outcome after acute ischemic stroke. Front. Neurol. 2018;9:1-9 doi: 10.3389/fneur.2018.00901.

24. Jokivarsi KT, Hiltunen Y, Tuunanen PI, Kauppinen RA, Gröhn OH. Correlating tissue outcome with quantitative multiparametric MRI of acute cerebral ischemia in rats. J. Cereb. Blood Flow Metab. 2010 doi: 10.1038/jcbfm.2009.236.

25. Sun PZ. Fast correction of $\mathrm{B} 0$ field inhomogeneity for $\mathrm{pH}$-specific magnetization transfer and relaxation normalized amide proton transfer imaging of acute ischemic stroke without Zspectrum. Magn. Reson. Med. 2019;0:1-10 doi: 10.1002/mrm.28040.

26. Yu L, Chen Y, Chen M, et al. Amide proton transfer MRI signal as a surrogate biomarker of ischemic stroke recovery in patients with supportive treatment. Front. Neurol. 2019;10 doi: 10.3389/fneur.2019.00104.

27. Msayib Y, Harston GWJ, Tee YK, et al. Quantitative CEST imaging of amide proton transfer in acute ischaemic stroke. Neurolmage Clin. 2019;23:101833 doi:

10.1016/j.nicl.2019.101833.

28. Wang E, Wu Y, Cheung JS, et al. Mapping tissue $\mathrm{pH}$ in an experimental model of acute stroke - Determination of graded regional tissue $\mathrm{pH}$ changes with non-invasive quantitative amide proton transfer MRI. Neuroimage 2019;191:610-617 doi:

10.1016/j.neuroimage.2019.02.022.

29. Foo LS, Yap WS, Hum YC, Manan HA, Tee YK. Analysis of model-based and modelfree CEST effect quantification methods for different medical applications. J. Magn. Reson. 
2020;310 doi: 10.1016/j.jmr.2019.106648.

30. Lee J Bin, Park JE, Jung SC, et al. Repeatability of amide proton transfer-weighted signals in the brain according to clinical condition and anatomical location. Eur. Radiol. 2020 doi: 10.1007/s00330-019-06285-7.

31. Sun PZ. Demonstration of magnetization transfer and relaxation normalized $\mathrm{pH}$-specific pulse-amide proton transfer imaging in an animal model of acute stroke. Magn. Reson. Med. 2020 doi: 10.1002/mrm.28223.

32. Sun PZ, Benner T, Kumar A, Sorensen AG. Investigation of optimizing and translating $\mathrm{pH}$-sensitive pulsed-chemical exchange saturation transfer (CEST) imaging to a 3T clinical scanner. Magn. Reson. Med. 2008 doi: 10.1002/mrm.21714.

33. Sun PZ, Cheung JS, Wang E, Benner T, Sorensen AG. Fast multislice pH-weighted chemical exchange saturation transfer (CEST) MRI with Unevenly segmented RF irradiation. Magn. Reson. Med. 2011;65:588-594 doi: 10.1002/mrm.22628.

34. Sun PZ, Benner T, Copen WA, Sorensen AG. Early experience of translating pHweighted MRI to image human subjects at 3 tesla. In: Stroke. ; 2010. doi:

10.1161/STROKEAHA.110.595777.

35. Sun PZ, Wang E, Cheung JS, Zhang X, Benner T, Sorensen AG. Simulation and optimization of pulsed radio frequency irradiation scheme for chemical exchange saturation transfer (CEST) MRI-demonstration of pH-weighted pulsed-amide proton CEST MRI in an animal model of acute cerebral ischemia. Magn. Reson. Med. 2011;66:1042-1048 doi: 10.1002/mrm.22894.

36. Zhao X, Wen Z, Huang F, et al. Saturation power dependence of amide proton transfer image contrasts in human brain tumors and strokes at $3 \mathrm{~T}$. Magn. Reson. Med.

2011;66:1033-1041 doi: 10.1002/mrm.22891.

37. Sun PZ, Cheung JS, Wang E, Lo EH. Association between $\mathrm{pH}$-weighted endogenous amide proton chemical exchange saturation transfer MRI and tissue lactic acidosis during acute ischemic stroke. J. Cereb. Blood Flow Metab. 2011;31:1743-1750 doi:

10.1038/jcbfm.2011.23.

38. Terreno E, Stancanello J, Longo D, et al. Methods for an improved detection of the MRICEST effect. Contrast Media Mol. Imaging 2009 doi: 10.1002/cmmi.290.

39. Zaiss M, Xu J, Goerke S, et al. Inverse Z-spectrum analysis for spillover-, MT-, and T1corrected steady-state pulsed CEST-MRI - application to $\mathrm{pH}$-weighted MRI of acute stroke. NMR Biomed. 2014;27:240-252 doi: 10.1002/nbm.3054.

40. Li H, Zu Z, Zaiss M, et al. Imaging of amide proton transfer and nuclear Overhauser enhancement in ischemic stroke with corrections for competing effects. NMR Biomed. 2015 doi: 10.1002/nbm.3243.

41. Zaiß M, Schmitt B, Bachert P. Quantitative separation of CEST effect from magnetization transfer and spillover effects by Lorentzian-line-fit analysis of z-spectra. J. Magn. Reson. 2011;211:149-155 doi: 10.1016/j.jmr.2011.05.001.

42. Jones CK, Polders D, Hua J, et al. In vivo three-dimensional whole-brain pulsed steadystate chemical exchange saturation transfer at 7 T. Magn. Reson. Med. 2012 doi: 10.1002/mrm.23141.

43. Zhang XY, Wang F, Afzal A, et al. A new NOE-mediated MT signal at around $-1.6 \mathrm{ppm}$ for detecting ischemic stroke in rat brain. Magn. Reson. Imaging 2016;34:1100-1106 doi: 10.1016/j.mri.2016.05.002. 
44. Zhou IY, Wang E, Cheung JS, Zhang X, Fulci G, Sun PZ. Quantitative chemical exchange saturation transfer (CEST) MRI of glioma using Image Downsampling Expedited Adaptive Least-squares (IDEAL) fitting. Sci. Rep. 2017;7:84 doi: 10.1038/s41598-01700167-y.

45. Zhou IY, Lu D, Ji Y, et al. Determination of multipool contributions to endogenous amide proton transfer effects in global ischemia with high spectral resolution in vivo chemical exchange saturation transfer MRI. Magn. Reson. Med. 2019;81:645-652 doi: 10.1002/mrm.27385.

46. Heo HY, Zhang Y, Lee DH, Hong X, Zhou J. Quantitative assessment of amide proton transfer (APT) and nuclear overhauser enhancement (NOE) imaging with extrapolated semisolid magnetization transfer reference (EMR) signals: Application to a rat glioma model at 4.7 tesla. Magn. Reson. Med. 2016 doi: 10.1002/mrm.25581.

47. Chappell MA, Donahue MJ, Tee YK, et al. Quantitative Bayesian model-based analysis of amide proton transfer MRI. Magn. Reson. Med. 2013;70:556-567 doi:

$10.1002 / \mathrm{mrm} .24474$.

48. Msayib Y, Harston GWJ, Sheerin F, et al. Partial volume correction for quantitative CEST imaging of acute ischemic stroke. Magn. Reson. Med. 2019 doi: 10.1002/mrm.27872.

49. Harston GWJ, Tee YK, Blockley N, et al. Identifying the ischaemic penumbra using $\mathrm{pH}-$ weighted magnetic resonance imaging. Brain 2015;138:36-42 doi: 10.1093/brain/awu374.

50. Zhou J, Wilson DA, Sun PZ, Klaus JA, Van Zijl PCM. Quantitative Description of Proton Exchange Processes between Water and Endogenous and Exogenous Agents for WEX, CEST, and APT Experiments. Magn. Reson. Med. 2004 doi: 10.1002/mrm.20048.

51. Sun PZ, Zhou J, Sun W, Huang J, Van Zijl PCM. Suppression of lipid artifacts in amide proton transfer imaging. Magn. Reson. Med. 2005;54:222-225 doi: 10.1002/mrm.20530.

52. Sun PZ, Zhou J, Sun W, Huang J, Van Zijl PCM. Detection of the ischemic penumbra using pH-weighted MRI. J. Cereb. Blood Flow Metab. 2007;27:1129-1136 doi: 10.1038/sj.jcbfm.9600424.

53. Wu L, Jiang $\mathrm{L}$, Sun PZ. Investigating the origin of $\mathrm{pH}$-sensitive magnetization transfer ratio asymmetry MRI contrast during the acute stroke: Correction of T1 change reveals the dominant amide proton transfer MRI signal. Magn. Reson. Med. 2020:1-11 doi:

$10.1002 / \mathrm{mrm} .28313$. 